\title{
SELECTED CHARACTERISTICS OF BUSINESS ENVIRONMENT IN VISEGRAD REGION
}

\author{
Michaela Bruothová, František Hurný
}

Business environment is considered to be an important factor that affects the competitiveness of the country or region. The assessment of business environment is subject to analysis realized by many national as well as internationally accepted institutions, whose outputs have usually form of composite indices reflecting the quality of the business environment. The aim of the article is to investigate the relationship between different indices of the quality of business environment on one side and selected macroeconomic indicators and country's credit rating on the other side. The analysis concentrates on the countries of Visegrad four region (V4) - Slovakia, Czech Republic, Hungary and Poland. The following indices are analyzed: Ease of Doing Business created by the World Bank Group, Global Competitiveness Index, Index of Economic Freedom, rating from The World Competitiveness Yearbook and Fragile State Index. We use the real gross domestic product, unemployment rate and inflation rate as the macroeconomic indicators and the results of the country's credit rating evaluated by Moody's, Standard \& Poor's and Fitch Ratings. The analysis is based on the country level data for the 2005-2014 period derived from the official statistical reports of World Bank, World Economic Forum, Institute for Management Development, The Heritage Foundation, Fund for Peace and Eurostat. The analysis is performed through correlation analysis using Pearson as well as Spearman correlation coefficients. The results of our analysis indicate that relationship between different indices of the quality of business environment and selected macroeconomic indicators or country's credit rating is country specific.

\section{Keywords}

business conditions, quality of business environment, macroeconomic indicators, country's credit rating, V4 countries

\section{Introduction}

Business environment can be defined as a set of economic, legal and institutional conditions that affect the firms' behavior in positive or negative way, but usually cannot be controlled by these firms. Demjanová (2009) describes the business environment as business conditions that promote or hinder the creation and development of enterprises. The importance of a well-functioning legal and regulatory system in creating an effective market economy is now widely accepted. After all, a poor contracting and regulatory environment can raise the cost of doing business with knock-on effects to employment, output, investment, productivity, and living standards (Besley, 2015). It has been also noted that the barriers to doing business vary widely across regions and countries, and it has been argued that the business environment will affect aggregate performance, as well as expert influence on the operation of financial markets (Commander, Svejnar, 2011). 
Business environment and its attractiveness are highly connected with the phase of transformation process of each economy. Countries of V4 region - Slovakia, Czech Republic, Hungary and Poland - are relatively young market economics with business environment which has started to change in 1989. Business environment was influenced by transformation, liberalization, globalization and other factors. Positive influence of their membership in European Union is considered to be unquestionable. Witkowska (2007) states that implementation of the European policies has impact on some elements of business environment of V4 countries. This environment is influenced by implementation of trade, competition, consumer protection, environmental, public procurement, social, transport and socio-economic cohesion policies and also policy towards small and medium enterprises. Implementation of all these policies helped to improve business environment in V4 countries. Despite similarity in economic structures and in the phase of transformation process, the development of economies of V4 countries has progressed differently.

Level of development of the economy is most commonly assessed by standard economic indicators such as gross domestic product, gross domestic product deficit, unemployment rate, inflation rate, exchange rate and many others. Country's credit rating from reputable credit rating agencies is another very often used and respected source of information especially on the risk of doing business in the country. The assessment of business environment is subject to analysis realized by many national as well as internationally accepted institutions, whose outputs have usually form of composite indices reflecting the quality of the business environment. Kolko, Neumark and Mejia (2013) state that business climate indexes summarize policies (and other factors) that might affect economic growth, and these indexes, published by many national organizations, often loom large in policy debates about economic growth.

In this paper we examine five state business climate indices that are frequently used as indicators reflecting the quality of the business environment of V4 countries. Our aim is to provide a preliminary look at the relationship among these indices on one hand and selected macroeconomic indicators (economic growth, unemployment and inflation) and country's credit rating of these countries on the other hand.

\section{Literature Review}

Measuring a state's business climate is not a new idea. Erickson (1987) points out that the basis for the original business climate indices were a series of comparative cost analyses that took place in the 1950s and 1960s. These analyses were relatively simplistic and focused mainly on comparing the cost structures of manufacturing industries across the states. The popularization of these early studies in academia and in the general public led to a heightened interest in producing indices that examine state competitiveness and business climate (VanMetre and Hall, 2011).

In general, nature of the indices measuring the quality of the business environment can be different. In terms of index construction, we can distinguish between unique and composite indices. A unique index is based on data obtained from special survey that tracks only the purpose. On the other side, a composite index is derived from number of existing indicators and surveys. Composite rates include more details, but overall, they are often criticized because of incompatibility of input indicators that is derived primarily from their diversity. Under the nature of the data, indices can be objective or subjective. Objective indices are calculated on objective measureable data, for example the average length of commercial disputes. Subjective 
indices are based on subjective views of respondents. Many aspects of the business environment cannot be evaluated by objective data, thus, almost all indicators reflecting the quality of the business environment have subjective nature (Körner, Kudrna, Vychodil, 2002).

Many economic studies use the business environment indicators as either the left- or right hand side of regressions. In each case, the authors report patterns that emerge in comparison across countries. In most cases, the concern is whether a particular indicator is correlated with aggregate or firm-level outcomes, or whether, if used as a left-hand side variable, the indicators are correlated with country characteristics, history, or institutions (Besley. 2015). The following literature review illustrates that the results of the studies are mixed.

Djankov, McLiesh and Ramalho (2006) found a positive relationship between economic growth and the Doing Business indicator. Similar results we can find in work of Gillanders and Whelan (2014). Their principal finding is that the Doing Business indicator emerges as the key explanatory variable in a wide range of instrumental variables regressions for income per capita and has significant explanatory power for longer-run growth.

Research focused on the index called Economic Freedom of North America has found a positive relationship between economic freedom and entrepreneurial activity (Campbell and Rogers, 2007; Campbell et al., 2007-08; Hall and Sobel, 2008). Also Garrett and Rhine (2010) assessed the relationship between the same index and state employment growth. They identified positive and statistically significant relationship. While the relationship between economic freedom and entrepreneurship is pretty clearly established, economic freedom is a very broad concept and encompasses many factors that might not be directly related to the entrepreneurial environment. Perhaps indices more closely related to the business environment might be better indicators of the institutional environment of the business (Van Metre and Hall, 2011).

The evidence of Bittlingmayer, Eathington and Hall (2005) suggests that for some indexes a business climate ranking predicts positive economic outcomes. They found that indexes more narrowly focused on tax policies are more likely to have positive relationships with growth than are broader measures, but also that indexes with these positive relationships explain little of the variation in economic growth. Kolko, Neumark and Mejia (2013) examined the relationship between a large set of state business climate indexes and state economic growth with focus on growth in employment, total wages and Gross State Product. They presented detailed information on what the indexes capture and analyzed whether they predict economic growth. Indexes focused on productivity do not predict economic growth while indexes emphasizing taxes and costs predict growth of employment, wages and output.

The results of Commander and Svejnar (2011) indicate that widely used country-level indicators of business environment provided by the Heritage Foundation and the World Bank do not provide much evidence of a negative relationship between the constraining environment and firm performance. VanMetre and Hall (2011) examined the relationship between six national indices that are often used as indicator of how "business friendly" is state and entrepreneurial activity among the fifty US states. They found that many of the business climate indices are not useful in explaining entrepreneurial activity and further research is needed to better understand the relationship between these indices and entrepreneurship.

The outlined literature review shows different findings on existence of relation between business climate indices and economic growth. There is also a gap in relevant literature focused on Central European countries in this field. Therefore, the aim of the article is to investigate the relationship between different indices of the quality of business environment on one side and selected macroeconomic indicators and country's credit rating on the other side. The analysis concentrates on the countries of V4 region. 


\section{Data and Methodology}

Following indices of the quality of business environment are analyzed in this paper: Ease of Doing Business $(E o D B)$ created by the World Bank Group, Global Competitiveness Index $(G C I)$, Index of Economic Freedom ( $I O E F)$, rating from The World Competitiveness Yearbook $(W C Y)$ and Fragile State Index (FSI). For Ease of doing Business, Global Competitiveness Index and rating from The World Competitiveness Yearbook we used ranking, so that the lower value is better. In case of Index of Economic Freedom and Fragile State Index we used index value (a higher value of these indices means the higher quality of the environment).

We use the real gross domestic product growth rate (RGDP), unemployment rate (Unempl) and inflation rate ( $I n f l$ ) as the macroeconomic indicators and the results of the country's credit rating evaluated by Moody's $(M)$, Standard \& Poor's $(S P)$ and Fitch Ratings $(F)$.

The analysis is based on the country level data for the 2005-2014 periods in case of the values of the business environment indices. In case of the macroeconomic indicators and country's credit ratings we used data for the 2004-2013 periods in order to find out, whether the trends of development of these variables is reflected in the business environment indices. The focus is on four countries of Visegrad region - Slovakia $(S K)$, Czech Republic (CZ), Hungary $(H U)$ and Poland $(P L)$. The dataset is derived from the official statistical reports of World Bank, World Economic Forum, and Institute for Management Development, The Heritage Foundation, Fund for Peace and Eurostat. The analysis is performed through correlation analysis using Pearson as well as Spearman correlation coefficients in which values of dependent variables business environment indices in particular period were correlated with values of explanatory variables in previous period.

The following text explains the aspects that are being measured and construction of each of five selected indices employed in the empirical section of the paper.

\section{Ease of Doing Business}

The World's Bank Doing Business project was launched in 2002. It measures the environment in which businesses operate in countries across the world. The centerpiece of the project is the annual Doing Business report, which currently includes 11 sets of indicators for 189 economies. The study contains quantitative measures of regulations for starting a business, dealing with construction permits, employing workers, registering property, getting credit, protecting investors, taxes, trading across borders, enforcing contracts, getting an electricity connection and closing a business. The study has become one of the flagship knowledge products of the World Bank Group in the field of private sector development, and is claimed to have motivated the design of several regulatory reforms in developing countries. The study presents every year a detailed analysis of costs, requirements and procedures regarding specific type of private firm in all countries, and then, it creates rankings for every country (The World bank, 2010).

\section{Global Competitiveness Index}

The Global Competitiveness Report is a yearly report published by the World Economic Forum. Since 2004, the Global Competitiveness Report ranks countries based on the Global Competitiveness Index. The report assesses the ability of countries to provide high levels of prosperity to their citizens. This in turn depends on how productively a country uses available resources. Therefore, the Global Competitiveness Index measures the set of institutions, 
policies, and factors that set the sustainable current and medium-term levels of economic prosperity. It is made up of over 110 variables, of which two thirds come from the Executive Opinion Survey, and one third comes from publicly available sources. The variables are organized into twelve pillars of competitiveness: institutions, infrastructure, macroeconomic environment, health and primacy education, higher education and training, goods market efficiency, labor market efficiency, financial market development, technological readiness, market size, business sophistication and innovation (World Economic Forum, 2012).

\section{Index of Economic Freedom}

The Index of Economic Freedom joints a series of 10 economic measurements created by the Heritage Foundation and Wall Street Journal. The Index's definition of economic freedom is the following; Economic freedom is the fundamental right of every human to control his or her own labor and property. In an economically free society, individuals are free to work, produce, consume, and invest in any way they please, with that freedom both protected by the state and unconstrained by the state. In economically free societies, governments allow labor, capital and goods to move freely, and refrain from coercion or constraint of liberty beyond the extent necessary to protect and maintain liberty itself. The index scores nations on 10 broad factors of economic freedom using statistics from organizations like the World Bank, the International Monetary Fund and the Economist Intelligence Unit: business freedom, trade freedom, monetary freedom, government size, fiscal freedom, property rights, investment freedom, financial freedom, freedom from corruption, labor freedom. The 10 factors are averaged equally into a total score (The Heritage Foundation, 2015).

\section{The World Competitiveness Yearbook rating}

The World Competitiveness Yearbook is an annual report published by the Swiss-based International Institute for Management Development on the competitiveness of nations and has been published since 1989 (Institute for Management Development, 2015). The yearbook benchmarks the performance of 60 countries based on 333 criteria measuring different facets of competitiveness. It uses two types of data, two thirds are hard statistical data from official international and national sources and one third are survey data from Executive Opinion Survey.

\section{Fragile State Index}

The Fragile States Index (formerly the Failed States Index) is an annual report published by the United States think-tank the Fund for Peace and the magazine Foreign Policy since 2005. The list only assesses sovereign states (as determined by membership in the United Nations). Ranking is based on the total scores of the 12 indicators (economic indicators: uneven economic development, poverty and economic decline; social indicators: demographic pressures, refugees and internally displaced persons, group grievance, human flight and brain drain; political and military indicators: state legitimacy, public services, human rights and rule of law, security apparatus, factionalized elites, external intervention). For each indicator, the ratings are placed on a scale of 0 to 10 , with 0 being the lowest intensity (most stable) and 10 being the highest intensity (least stable). The total score is the sum of the 12 indicators and is on a scale of 0-120 (The Fund for Peace, 2014). 


\section{Results and Discussion}

Over the past decade, the V4 countries fastened growth rate of their economies and gradually got above average growth rate of the European Union. The integration with the economies of the European Union has been considered as a key factor of above average economic performance in recent years. It opened up the new trade and investment opportunities to these countries and promoted institutional and macroeconomic reforms. I It also accelerated the process of convergence to the level of income per capita of developed Western countries (Spišáková, Pétrová, 2011).Figures 1-3 show the trends of real GDP growth rate, unemployment rate and inflation rate in V4 countries in period of 2005-2014. Slovakia and the Czech republic had the best starting position in terms of GDP level in reporting period. They achieved high GDP growth in connection with relatively low inflation. The economic crisis caused a significant decline in GDP in 2009, a further decrease occurred again in 2012. In the following period, GDP growth rate started to grow in all V4 countries. The smallest fluctuations of the GDP growth rate and the least negative impacts on GDP during the economic crisis can be seen in case of Poland, which in comparison to other V4 countries has more closed economy with a large internal market. In the pre-crisis period, unemployment fell in all economies of the V4 region, the lowest level reached in 2008. Since 2009 the unemployment rate gradually increased, except in 2011 when decreased slightly.

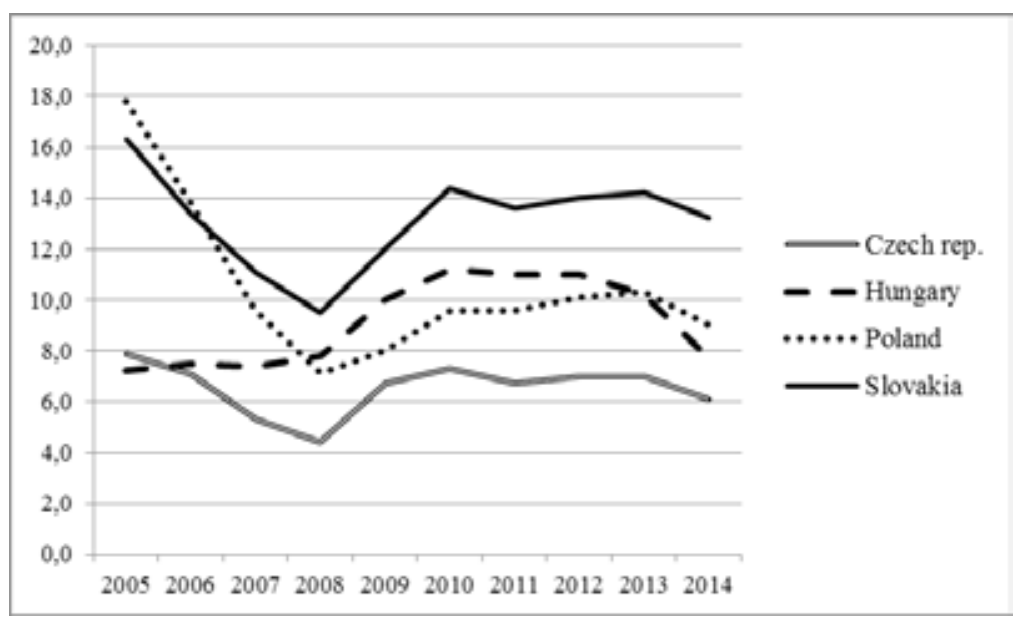

Source: own processing according to data from Eurostat

Figure 1 Real GDP growth rate in V4 countries in the years 2005-2014 (\%) 


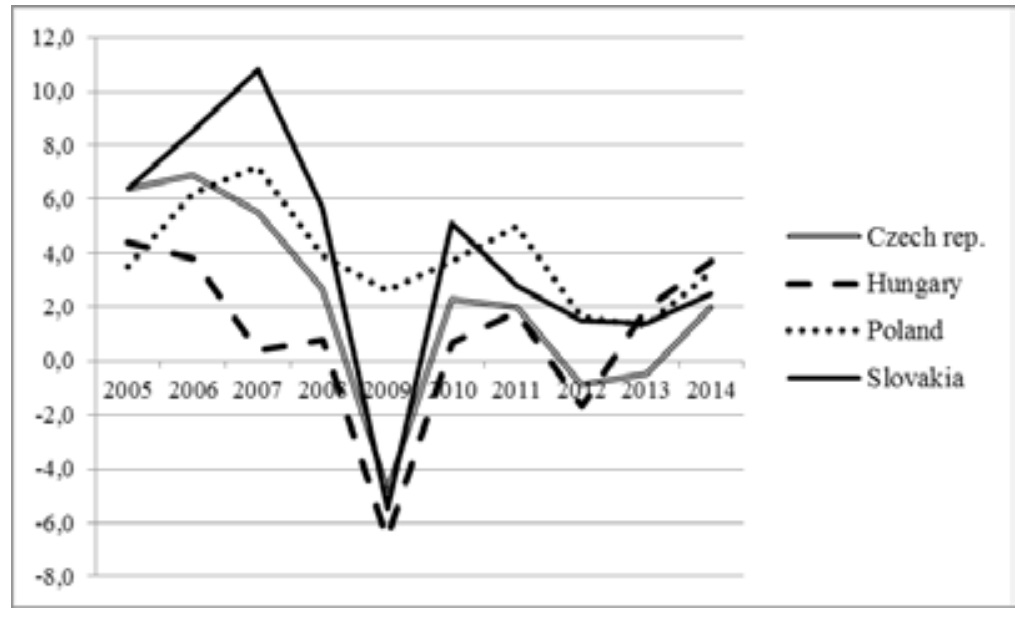

Source: own processing according to data from Eurostat

Figure 2 Inflation rate in V4 countries in the years 2005-2014 (\%)

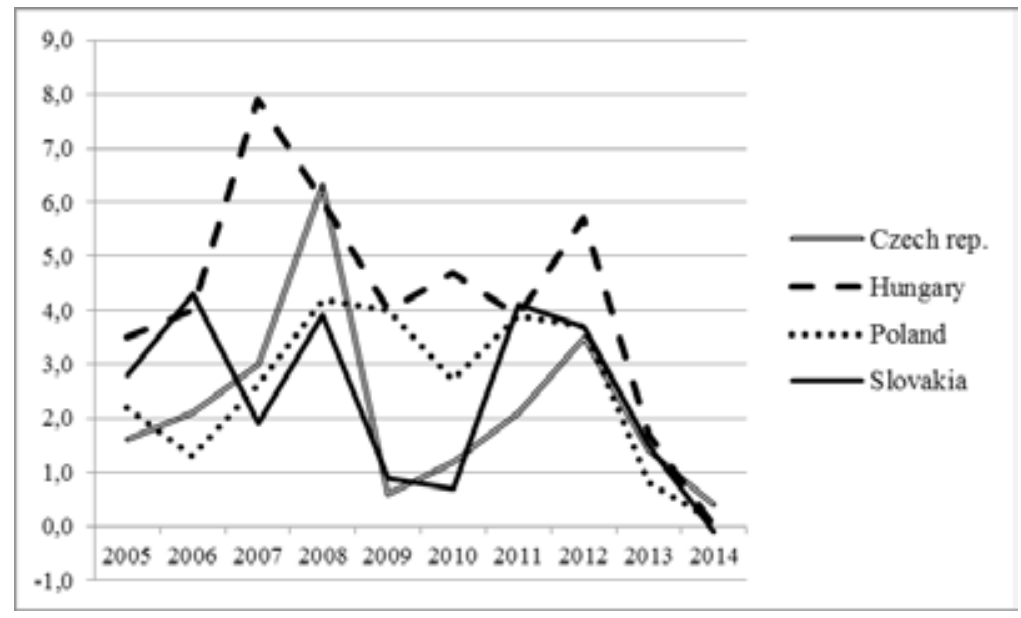

Source: own processing according to data from Eurostat

Figure 3 Unemployment rate in V4 countries in the years 2005-2014 (\%) 


\begin{tabular}{|c|c|c|c|c|c|c|c|}
\hline Variable & Mean & Std Dev & Median & Min & $\operatorname{Max}$ & $\begin{array}{l}\text { Kolmogorov- } \\
\text {-Smirnov test }\end{array}$ & p Value \\
\hline EoDB_SK & 40.40000 & 5.75809 & 39.00000 & 32.00000 & 49.00000 & 0.22256354 & $>0.150$ \\
\hline IoEF_SK & 68.69000 & 1.39956 & 69.45000 & 66.40000 & 70.00000 & 0.29402820 & 0.015 \\
\hline GCI_SK & 55.60000 & 16.98496 & 53.50000 & 32.00000 & 78.00000 & 0.19368760 & $>0.150$ \\
\hline WCY_SK & 41.20000 & 6.98888 & 42.50000 & 30.00000 & 49.00000 & 0.20668322 & $>0.150$ \\
\hline FSI_SK & 137.20000 & 13.62025 & 143.50000 & 111.00000 & 146.00000 & 0.40987621 & $<0.010$ \\
\hline Unem_SK & 13.67000 & 1.89798 & 13.50000 & 9.50000 & 16.30000 & 0.18410846 & $>0.150$ \\
\hline RGDP_SK & 4.20000 & 4.50111 & 5.20000 & -5.50000 & 10.80000 & 0.17924041 & $>0.150$ \\
\hline Infl_SK & 3.13000 & 2.04072 & 3.25000 & 0.70000 & 7.50000 & 0.18321204 & $>0.150$ \\
\hline M_SK & 14.50000 & 0.70711 & 15.00000 & 13.00000 & 15.00000 & 0.36024994 & $<0.010$ \\
\hline SP_SK & 15.10000 & 0.87560 & 15.00000 & 13.00000 & 16.00000 & 0.35453644 & $<0.010$ \\
\hline Fitch_SK & 15.40000 & 0.96609 & 16.00000 & 13.00000 & 16.00000 & 0.33271960 & $<0.010$ \\
\hline EoDB_HU & 51.00000 & 6.91215 & 51.50000 & 41.00000 & 66.00000 & 0.23213749 & 0.128 \\
\hline IoEF_HU & 66.18000 & 1.32648 & 66.70000 & 63.50000 & 67.60000 & 0.22423664 & $>0.150$ \\
\hline GCI_HU & 53.00000 & 8.85689 & 55.00000 & 39.00000 & 63.00000 & 0.21380409 & $>0.150$ \\
\hline WCY_HU & 42.80000 & 5.02881 & 43.50000 & 35.00000 & 50.00000 & 0.16911822 & $>0.150$ \\
\hline FSI_HU & 135.70000 & 10.43552 & 141.00000 & 116.00000 & 142.00000 & 0.38722063 & $<0.010$ \\
\hline Unem_HU & 8.94000 & 1.91903 & 8.90000 & 6.10000 & 11.20000 & 0.22376096 & $>0.150$ \\
\hline RGDP_HU & 1.04000 & 3.35963 & 1.30000 & -6.60000 & 4.90000 & 0.22445977 & $>0.150$ \\
\hline Infl_HU & 4.82000 & 1.80296 & 4.35000 & 1.70000 & 7.90000 & 0.17537614 & $>0.150$ \\
\hline M_HU & 12.00000 & 2.53859 & 12.50000 & 9.00000 & 15.00000 & 0.18460444 & $>0.150$ \\
\hline SP_HU & 10.80000 & 1.39841 & 11.00000 & 9.00000 & 14.00000 & 0.34313743 & $<0.010$ \\
\hline Fitch_HU & 12.10000 & 1.79196 & 12.00000 & 10.00000 & 16.00000 & 0.20774791 & $>0.150$ \\
\hline EoDB_CZ & 60.90000 & 12.40475 & 63.50000 & 41.00000 & 75.00000 & 0.16721573 & $>0.150$ \\
\hline IoEF_CZ & 68.91000 & 2.28106 & 69.60000 & 64.60000 & 72.20000 & 0.18504331 & $>0.150$ \\
\hline GCI_CZ & 36.00000 & 4.83046 & 36.50000 & 29.00000 & 46.00000 & 0.16728040 & $>0.150$ \\
\hline WCY_CZ & 31.60000 & 2.67499 & 31.50000 & 28.00000 & 36.00000 & 0.13446660 & $>0.150$ \\
\hline FSI_CZ & 145.30000 & 14.29102 & 152.00000 & 118.00000 & 155.00000 & 0.37492608 & $<0.010$ \\
\hline Unem_CZ & 6.77000 & 1.14993 & 7.00000 & 4.40000 & 8.30000 & 0.27573002 & 0.030 \\
\hline RGDP_CZ & 2.45000 & 3.70413 & 2.50000 & -4.80000 & 6.90000 & 0.15165300 & $>0.150$ \\
\hline Infl_CZ & 2.44000 & 1.60914 & 2.10000 & 0.60000 & 6.30000 & 0.18367064 & $>0.150$ \\
\hline M_Č-CZ & 15.00000 & 0 & 15.00000 & 15.00000 & 15.00000 & - & - \\
\hline SP_CZ & 15.30000 & 1.25167 & 15.00000 & 14.00000 & 17.00000 & 0.29471108 & 0.015 \\
\hline Fitch_CZ & 15.60000 & 0.51640 & 16.00000 & 15.00000 & 16.00000 & 0.38071099 & $<0.010$ \\
\hline EoDB_PL & 61.50000 & 14.80428 & 66.00000 & 32.00000 & 76.00000 & 0.21706967 & $>0.150$ \\
\hline IoEF_PL & 62.21000 & 3.07840 & 61.75000 & 58.10000 & 67.00000 & 0.23251984 & 0.127 \\
\hline GCI_PL & 45.50000 & 4.99444 & 44.50000 & 39.00000 & 53.00000 & 0.19165835 & $>0.150$ \\
\hline WCY_PL & 42.40000 & 10.17841 & 40.00000 & 32.00000 & 58.00000 & 0.23525410 & 0.116 \\
\hline FSI_PL & 140.00000 & 14.20485 & 144.50000 & 113.00000 & 153.00000 & 0.35598483 & $<0.010$ \\
\hline Unem_PL & 11.49000 & 4.04240 & 9.85000 & 7.10000 & 19.00000 & 0.31576606 & $<0.010$ \\
\hline RGDP_PL & 4.01000 & 1.90464 & 3.80000 & 1.30000 & 7.20000 & 0.12302755 & $>0.150$ \\
\hline Infl_PL & 2.90000 & 1.18415 & 3.15000 & 0.80000 & 4.20000 & 0.22278636 & $>0.150$ \\
\hline M_PL & 14.00000 & 0 & 14.00000 & 14.00000 & 14.00000 & 0.52408518 & $<0.010$ \\
\hline SP_PL & 13.90000 & 0.31623 & 14.00000 & 13.00000 & 14.00000 & - & - \\
\hline Fitch_PL & 13.70000 & 0.48305 & 14.00000 & 13.00000 & 14.00000 & 0.43271960 & $<0.010$ \\
\hline
\end{tabular}


Following table 1 shows basic descriptive characteristics and testing statistics of studied variables.

Figure 4 shows the comparison of average values of analyzed indices of business environment of V4 countries in reviewed period.

Tables 2 and 3 show the results of correlation analysis using Pearson correlation coefficients and Spearman rank correlation coefficients. We used both correlations, because Pearson correlation strictly requires that the two variables follow the normal distribution, but Spearman rank correlation does not have such requirement. After checking the data set, we found that according to Kolmogorov-Smirnov test (Table 1) not all the variables are normally distributed. Use of Pearson correlation coefficient showed existence of considerably lot statistically not significant relations.. Relatively more statistically significant relations among indices of business environment and macroeconomic indicators of particular country have been detected using Spearman rank correlation coefficient that can indicate existence of rather non-linear relationship between studied variables.

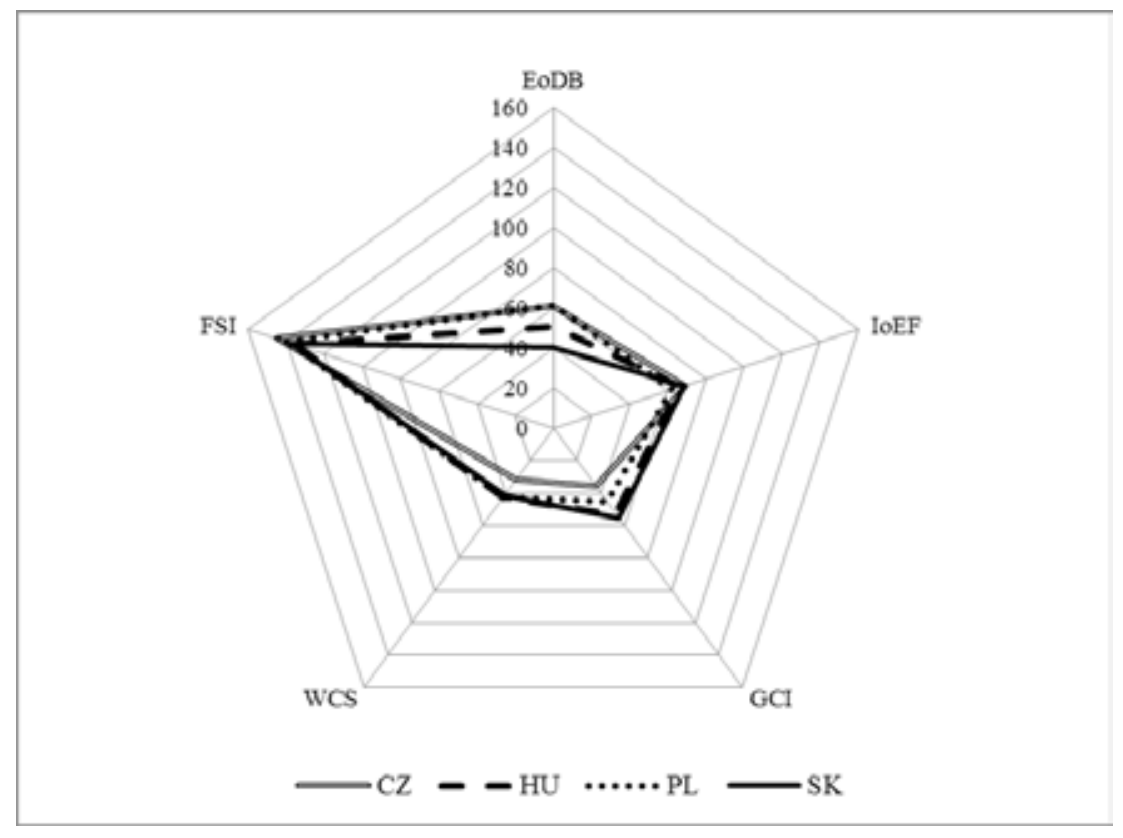

Source: own processing based on statistical reports of World Bank, World Economic Forum, Institute for Management Development, The Heritage Foundation and Fund for Peace Note: For Ease of doing Business, Global Competitiveness Index and rating from The World Competitiveness Yearbook the lower value is better. In case of Index of Economic Freedom and Fragile State Index a higher value of these indices means the higher quality of the environment.

Figure 4 The average value of selected indices of the quality of business environment in V4 countries in the years 2005-2014 


\begin{tabular}{|c|c|c|c|c|c|c|c|c|c|c|c|}
\hline \multirow[b]{2}{*}{ EoDB_SK } & \multicolumn{2}{|c|}{ Unempl } & \multicolumn{2}{|c|}{ RGDP } & Infl & \multicolumn{2}{|l|}{$\mathbf{M}$} & \multicolumn{2}{|l|}{ SP } & \multicolumn{2}{|l|}{ Fitch } \\
\hline & -0.11952 & & -0.41456 & & -0.19403 & 0.16374 & & 0.45399 & & 0.54728 & \\
\hline IoEF_SK & -0.46162 & & 0.24111 & & -0.41809 & 0.55576 & * & 0.35452 & & 0.19229 & \\
\hline GCI_SK & -0.19099 & & -0.54196 & & -0.49744 & 0.22203 & & 0.60068 & * & 0.76922 & $* * *$ \\
\hline WCY_SK & 0.31552 & & -0.80284 & $* * *$ & -0.28560 & -0.11242 & & 0.41398 & & 0.39824 & \\
\hline FSI_SK & -0.73982 & $* *$ & -0.23815 & & -0.54030 & 0.70375 & ** & 0.66895 & ** & 0.80388 & $* * *$ \\
\hline EoDB_CZ & -0.72698 & $* *$ & -0.17979 & & 0.48895 & - & & 0.25977 & & 0.33997 & \\
\hline IoEF_CZ & -0.34002 & & -0.69743 & $* *$ & -0.05340 & - & & 0.81219 & $* * *$ & 0.86215 & $* * *$ \\
\hline GCI_CZ & 0.27604 & & -0.52536 & & -0.11007 & - & & 0.66158 & $* *$ & 0.48998 & \\
\hline WCY_CZ & 0.64946 & $* *$ & 0.01682 & & -0.06557 & - & & 0.27212 & & -0.04826 & \\
\hline FSI_CZ & -0.57815 & * & -0.53430 & & 0.10137 & - & & 0.65284 & $* *$ & 0.71064 & ** \\
\hline EoDB_HU & 0.08795 & & 0.38230 & & -0.47967 & -0.09498 & & -0.13794 & & -0.10765 & \\
\hline IoEF_HU & 0.64854 & $* *$ & -0.50792 & & 0.00390 & -0.66982 & $* *$ & -0.76911 & $* * *$ & -0.79839 & $* * *$ \\
\hline GCI_HU & 0.53082 & & -0.46527 & & 0.05984 & -0.63749 & $* *$ & -0.74459 & $* *$ & -0.70708 & ** \\
\hline WCY_HU & 0.80918 & $* * *$ & -0.37039 & & -0.32671 & -0.85295 & $* * *$ & -0.70152 & $* *$ & -0.84831 & $* * *$ \\
\hline FSI_HU & 0.68034 & $* *$ & -0.59733 & * & -0.10181 & -0.67107 & $* *$ & -0.65175 & $* *$ & -0.74094 & $* *$ \\
\hline EoDB_PL & 0.04447 & & 0.62477 & * & 0.16543 & - & & 0.17800 & & -0.28744 & \\
\hline IoEF_PL & -0.51090 & & -0.72715 & $* *$ & 0.01676 & - & & 0.29790 & & 0.71957 & $* *$ \\
\hline GCI_PL & 0.55557 & * & 0.72360 & $* *$ & -0.31187 & - & & -0.38693 & & -0.62175 & * \\
\hline WCY_PL & 0.83428 & $* * *$ & 0.47491 & & -0.24614 & - & & -0.50400 & & -0.89944 & $* * *$ \\
\hline FSI_PL & -0.84231 & $* * *$ & -0.21684 & & -0.08257 & - & & 0.66786 & $* *$ & 0.77727 & $* * *$ \\
\hline
\end{tabular}

Table 2 Pearson correlation coefficients for V4 countries

Considering the results of the research, we cannot conclude that there are clear relations among business environment indices and macroeconomic indicators. Reasons can be sought in way of construction of analyzed indices of business environment, because they take into account official macroeconomic data of particular country on one hand as well as rather subjective perception of quality of business environment based on questionnaires on the other hand. Similarly, Körner, Kudrna and Vychodil (2002) argue that the indices are typically set to evaluate different aspects of the business environment and they are able to distinguish between strenghts and weaknesses of country's institutional framework. However, the indices themselves are unable to answer the question of why some components are better or worse, they also do not answer the question of whether these differences are real, or if it is just the difference in the perception of respondents. This apparent incompleteness can be removed only through deeper penetration into the problem in studies focused on specific countries and in comparative studies. 


\begin{tabular}{|c|c|c|c|c|c|c|c|c|c|c|c|c|}
\hline \multirow[b]{2}{*}{ EoDB_SK } & \multicolumn{2}{|c|}{ Unempl } & \multicolumn{2}{|c|}{ RGDP } & \multicolumn{2}{|l|}{ Infl } & \multicolumn{2}{|l|}{$\mathbf{M}$} & \multicolumn{2}{|l|}{ SP } & \multicolumn{2}{|c|}{ Fitch } \\
\hline & 0.03049 & & -0.61587 & * & -0.22561 & & -0.05931 & & 0.45705 & & 0.75012 & $* *$ \\
\hline IoEF_SK & -0.36970 & & 0.52727 & & -0.32121 & & 0.47161 & & 0.20113 & & -0.27742 & \\
\hline GCI_SK & -0.15152 & & -0.69697 & $* *$ & -0.41818 & & 0.12484 & & 0.49935 & & 0.87386 & $* * *$ \\
\hline WCY_SK & 0.31611 & & -0.85107 & $* * *$ & -0.43161 & & -0.01739 & & 0.65044 & ** & 0.57739 & * \\
\hline FSI_SK & -0.21474 & & -0.60741 & * & -0.41107 & & 0.12638 & & 0.37914 & & 0.88465 & $* * *$ \\
\hline EoDB_CZ & -0.70031 & $* *$ & -0.20061 & & 0.50610 & & - & & 0.47338 & & 0.32077 & \\
\hline IoEF_CZ & -0.32318 & & -0.76970 & $* * *$ & -0.21277 & & - & & 0.89893 & $* * *$ & 0.85280 & $* * *$ \\
\hline GCI_CZ & 0.14724 & & -0.60367 & ** & -0.01529 & & - & & 0.58788 & * & 0.46476 & \\
\hline WCY_CZ & 0.57362 & * & -0.14025 & & 0.10703 & & - & & 0.13566 & & 0.00000 & \\
\hline FSI_CZ & -0.52015 & & -0.75086 & $* *$ & -0.04939 & & - & & 0.95851 & $* * *$ & 0.86603 & $* * *$ \\
\hline EoDB_HU & 0.17847 & & 0.36199 & & -0.56618 & * & -0.26251 & & -0.44409 & & -0.38246 & \\
\hline IoEF_HU & 0.48632 & & -0.61212 & * & 0.13982 & & -0.62356 & * & -0.67858 & $* *$ & -0.59457 & * \\
\hline GCI_HU & 0.52134 & & -0.66870 & $* *$ & 0.10366 & & -0.70597 & $* *$ & -0.75971 & $* *$ & -0.66471 & $* *$ \\
\hline WCY_HU & 0.80793 & $* * *$ & -0.46201 & & -0.25610 & & -0.84840 & $* * *$ & -0.76658 & $* * *$ & -0.94426 & $* * *$ \\
\hline FSI_HU & 0.92403 & $* * *$ & -0.66172 & $* *$ & -0.10412 & & -0.82610 & $* * *$ & -0.50259 & & -0.82208 & $* * *$ \\
\hline EoDB_PL & -0.16566 & & 0.57576 & * & -0.06667 & & - & & 0.29013 & & -0.26591 & \\
\hline IoEF_PL & -0.34463 & & -0.63830 & $* *$ & 0.15198 & & - & & 0.29101 & & 0.80015 & $* * *$ \\
\hline GCI_PL & 0.50001 & & 0.63416 & $* *$ & -0.47562 & & - & & -0.35028 & & -0.57329 & * \\
\hline WCY_PL & 0.62964 & * & 0.48172 & & -0.46342 & & - & & -0.40867 & & -0.80260 & $* * *$ \\
\hline FSI_PL & -0.20924 & & -0.36474 & & -0.14590 & & - & & 0.52382 & & 0.64774 & $* *$ \\
\hline
\end{tabular}

Table 3 Spearman correlation coefficients for V4 countries

The most controversial relationships were found among business environment indices and country's credit rating. It can be explained by the fact that rating agencies take into account slightly different and more limited views on the country's business environment especially from riskiness of doing business point of view and they are more rigid in their evaluation that is not changing on regular basis. Business environment indices are more flexible and published regularly on yearly basis. The investors by their decision making on location of their investment usually respect the view of reputable rating agencies more than results of country's evaluation from different nongovernment organizations. Also, the change in country's credit rating can cause significant fluctuations of investment activity. As Ozturk (2014) states, although sovereign credit ratings constitute a small part of the credit rating industry, the impact of unexpected downgrades or upgrades has a huge potential to distort a well-functioning financial system. The rating agencies have recognized this fact and they are quite cautious in changing their evaluation of particular countries. Only in case of Poland, the evaluation through indices of 
business environment corresponds with country's credit rating. The reasons might be found in the fact that Poland has relatively closed economy in comparison to Slovak economy that is generally considered to be small, open and export-oriented (Bobenič Hintošová, Hliboká, 2015).

We can conclude that such meanings of different private entities often do not correspondent with official macroeconomic view on the environment. Thus, the business environment indices connect "macroview" with more "microview". For potential investor it means that the real microeconomic environment for doing business in particular country as evaluated by concerned entities (e. g. entrepreneurs, managers, or citizens), may be slightly different as officially declared level of macroeconomic environment.

Different nature of relation among studied variables in different countries might evoke different view of respondents on microeconomic business environment in particular countries. Hence, the relation among business environment indices and macroeconomic indicators are according to us country specific. Similar results can be found in work of Commander and Svejnar (2011) or Besley (2015).

Further research in this field, especially from the foreign direct investment point of view and their relationship to business environment indices respectively macroeconomic indicators could prove if the investors by their decision making on their investment abroad are driven by official evaluation of macroeconomic environment or rather by more complex indicators.

\section{Conclusion}

In our study, we identified the existence of statistically significant relationship among chosen of analyzed indices of the quality of business environment and macroeconomic indicators or country's credit rating in all four countries from Visegrad region. The contradictory relations were found among business environment indices and country's credit rating. We also cannot prove the clear and unambiguous relationship among business environment indices and macroeconomic indicators.

According to results of our analysis we can conclude that relationship between different indices of the quality of business environment on one side and selected macroeconomic indicators and country's credit rating on the other side is country specific and it is hardly possible to generalize it. As Besley (2015) states, such differences reinforce the need to look beyond the aggregate measures and to drill down into specific performances across the indicators. Finally, the findings suggest that the further research focused mainly on foreign direct investment point of view is needed to extent these results. Also a use of panel data analysis would be a useful extension.

\section{Literature}

Besley, T. (2015). Law, Regulation, and the Business Climate: The Nature and influence of the World Bank Doing Business Project, Journal of Economic Perspectives, 29 (3), pp. 99-120

Bittlingmayer, G., Eathington, L., Hall, A. P. (2005). Business climate Indexes: Which Work, Which Don't, and What Can They Say About the Kansas Economy?, Research Report, Kansas, Inc., Topeka, K.S.

Bobenič Hintošová, A., Hliboká, L. (2015). The relationship between Industry Structure and International Competitiveness: Evidence from a Small Open Economy, Journal of Applied Economic Sciences, 10 (5), pp. 710-715. 
Campbell, N., Rodgers, T. (2007). Economic Freedom and Net Business Formation, Cato Journal, 27, pp. 23-36

Campbell, N., Rodgers, T., Heriot, K. (2007-08). The Economic Freedom Index as a Determinant of Firm Births and Firm Deaths, Southwest Business and Economic Journal, 16, pp. 37-50

Commander, S., Svejnar, J. (2011). Business Environment Exports, Ownership, and Firm Performance, Review of Economic and Statistics, 93 (1), pp. 309-337

Demjanová, L. (2009), Podnikatelské prostredie ako faktor konkurencieschopnosti v krajinách V4 v rokoch 2005-2009. Zborník príspevkov z medzinárodnej vedeckej konferencie Semafor '09. pp. 58-66

Djankov, S., McLiesh, C., Ramalho, R. M. (2006). Regulation and Growth, Economic Letters, 92 (3), pp. 395-401

Erickson, R. (1987). Business Climate Studies: A Critical Evaluation, Economic Development Quarterly, 1, pp. 62-71

Garrett, T., Rhine, R. 2010. Economic Freedom and Employment Growth in U.S. States, Working Paper, 006A, Federal Reserve Bank of St. Louis, MO

Gillanders, R., Whelan K. 2014, Open for Business? Institutions, Business Environment and Economic crisis, 67 (4), pp. 535-558

Hall, J., Sobel, R. (2008), Institutions, Entrepreneurship, and Regional Differences in economic Growth, Southern Journal of Entrepreneurship, 1, pp. 66-96

Institute for Management Development. (2015). Methodology. Available at: http://www.imd.org/wcc/ research-methodology/. Accessed 19 November 2015

Kolko, J., Neumark, D., Mejia, M. C. (2013). What Do Business Climate Indexes Teach Us about State Policy and economic Growth, Journal of Regional Science, 53 (2), pp. 220-255

Körner, P., Kudrna, Z., Vychodil, O. (2002). Měření kvality podnikatelského prostředí ve stř̌ední Evropě, Finance a úvěr, 12, pp. 674-697

Oztur, H. (2014). The Origin of Bias in Sovereign Credit Ratings: Reconciling Agency Views with Institutional Quality. Journal of Developing Areas, 4 (48). pp. 161-188

Spišáková, E., Pétrová, R. (2011). Vplyv hospodárskej krízy na vybrané makroekonomické ukazovatele, Transfer inovácií, 21, pp. 240-248

The Fund for Peace. (2014). Fragile State Index 2014. Available at: http://library.fundforpeace.org/ library/cfsir1423-fragilestatesindex2014-06d.pdf. Accessed 19 November 2015

The Heritage Foundation. (2015). About the Index. Available at: http://www.heritage.org/index/about. Accessed 19 November 2015

The World Bank. (2010). Doing Business 2010. Available at: http://www.doingbusiness.org/ /media/ GIAWB/Doing\%20Business/Documents/Annual-Reports/English/DB10-FullReport.pdf. Accessed 19 November 2015

Van Metre, B. J., Hall, J (2011). How Friendly To Entrepreneurs Are "Business friendly" Policies?, Journal Business and Economic Perspectives, 28 (1), pp. 105-116

Witkowska, J. (2007). Foreign Direct Investment in the Changing Business Environment of the European's New Member states, Global Economy Journal, 7 (4), pp. 1-30

World Economic Forum. (2012). The Global Competitiveness Report 2011-2012. Available at: http:// www3.weforum.org/docs/WEF_GCR_Report_2011-12.pdf. Accessed 19 November 2015

Michaela Bruothová

František Hurný michaela.bruothova@euke.sk

University of Economics in Bratislava Faculty for Business Economics, Department of Management Tajovského 13, 04130 Košice, Slovakia 